Research Journal of Applied Sciences, Engineering and Technology 5(9): 2809-2820, 2013

DOI: $10.19026 /$ rjaset.5.4810

ISSN: 2040-7459 e-ISSN: 2040-7467

(C) 2013 Maxwell Scientific Publication Corp.

$\begin{array}{lll}\text { Submitted: March 03, } 2012 & \text { Accepted: March 24, } 2012 & \text { Published: March 20, } 2013\end{array}$

\title{
Research Article \\ Public Sector Perception of Barriers to the use of Public-Private Partnerships (PPP) in Nigeria-Findings from a Questionnaire Survey
}

\author{
${ }^{1}$ AbdulGaniyu Otairu, ${ }^{2}$ Abdullahi A.Umar, ${ }^{2}$ Noor Amila A. Zawawi and ${ }^{3}$ Abd Hamid K. Pakir \\ ${ }^{1}$ Insitu-Holmes Ltd, Suite C-59, 2nd floor, IDE Plaza Utako, Abuja, Nigeria \\ ${ }^{2}$ Department of Civil Engineering, Universiti Teknologi PETRONAS, Bandar Seri Iskandar 31750 \\ Tronoh, Perak, Malaysia \\ ${ }^{3}$ School of Housing, Building \& Planning, Universiti Sains Malaysia, 11800 Minden, Palau-Pinang, \\ Penang, Malaysia
}

\begin{abstract}
The availability of basic infrastructure plays a great role in the economic development of any nation and studies have shown the effectiveness of Public-Private Partnerships (PPP) or Private Finance Initiative (PFI) to help developing countries overcome their infrastructure problems. This paper presents findings from a questionnaire survey conducted among public sector officials with the objectives of investigating and ranking the major barriers and solutions to the use of PPPs in Nigeria. The results show that, high rate of corruption in government, lack of clear government policy on infrastructure, and lack of adequate security were the major barriers. Consequently, the elimination of corruption in government, improving the knowledge of officials in PPP procurement strategy, developing a clear government policy on infrastructure, maintaining political stability, and developing strong financial institutions were found to be the most significant factors that could improve the use of PPP in Nigeria
\end{abstract}

Keywords: Corruption, PPP/PFI, procurement strategy, public infrastructure, public sector

\section{INTRODUCTION}

Public-Private Partnerships (PPP) or Private Finance Initiatives (PFI) as they are referred to in some regions are the new age procurement strategy used by many governments across the world to provide the much needed world-class public services for their citizenry. (Ang, 2008) Found that "the provision of an adequate infrastructure base is an effective tool for stimulating FDI inflows", and thereby helping economic growth. However, driven by dwindling revenue streams, recurrent year-on-year budget deficits and failure of the civil service to efficiently deliver public services, governments around the globe have looked in the direction of the private sector for assistance in providing the required public services and infrastructure.

"Public-Private Partnerships are one form of the current liberalisation policy aimed at changing the way public services are produced and delivered to the public. PPPs open up the possibilities for the provision of public services, not only to come exclusively from organisations owned and controlled by the public sector but also from both public and private sectors in partnerships” (Broadbent and Laughlin, 2003) and foreign state-owned company is considered a private entity (Roger, 1999). The adoption of this procurement strategy is not limited to particular types of governance structure or stage of economic development, rather developed and developing economies all practice it under different names, formats and for different reasons. The lack of world class efficient infrastructure in developing countries is one of the major reasons why Foreign Direct Investments (FDI) are scarce in developing countries in Africa, as "it is generally known that endowment for infrastructures is one of the most important conditions for economic growth in any country” (Benito et al., 2008), This pre-condition for economic growth has been recognised by developing countries in East Asia, hence their heavy investments in infrastructure development. However, Africa is a region where adequate basic infrastructures are still lacking, and where they are present, they do not meet required standards. Nigeria, with all its oil wealth is one of such country with decaying and insufficient public infrastructure hence requires the adoption of PPPs to curtail the downward trend of public services.

In 2004, 205 national Public-Private Partnerships contracts were signed worldwide involving 52 billion US\$ in investments (De Brux, 2010). In terms of regions, in Asia, "a joint Asian Development Bank, Japan Bank for International Co-operation and World

Corresponding Author: AbdulGaniyu Otairu, Insitu-Holmes Ltd, Suite C-59, 2nd floor, IDE Plaza Utako, Abuja, Nigeria This work is licensed under a Creative Commons Attribution 4.0 International License (URL: http://creativecommons.org/licenses/by/4.0/) 
Bank estimate is that East Asia alone has infrastructure needs totalling US\$200 billion a year over the next five years. Around two-thirds of this expenditure needs to be new investment, with the balance on upkeep of existing assets" (Siang, 2008), while in Europe, (BlancBrude et al., 2009) more than one thousand PublicPrivate Partnership (PPP) contracts have been signed in the EU over the past 15 years, representing a capital value of almost $€ 200$ billion. Fixed capital formation through PPP projects has become big enough to have macroeconomic and systemic significance in a number of countries, including Portugal and Spain in addition to the UK". However, in terms of investments specific to the UK, "in 2005-06 was approximately £6 billion representing $12 \%$ of the total private involvement in public services" (HM Treasury, 2006) cited in (NAO, 2008), in Australia on the other hand, some \$A17 billion in commitments to investment in PFP projects has been made by different Australian states (AusCID, 2002) cited in English and Guthrie (2003) while in Malaysia, under the $10^{\text {th }}$ Malaysian Plan, the government intends to execute 52 High Impact Projects (HIP) worth about RM 63 billion (approx. US\$ 21,000,000,000.00 ) using PPP/PFI (EPU, 2010). With all the foregoing in terms of investments in PPP/PFI across the globe, there seems to be loathsomeness in adopting this procurement strategy in Nigeria. Therefore, this study intends to identify and rank the major barriers to the adoption of PPPs/PFIs in Nigeria and also identify and rank the solution factors that can help overcome the present state of lethargy.

\section{PPPS/PFIS IN NIGERIA}

The use of PPPs in Nigeria is still at its nascent stage although a number of concession contracts have been awarded, the volume compared to what is actually required is less than adequate. Even the legislation empowering the use of private finance for public services was not signed into law until late 2005. Section 1, subsection 1 of the Act states that:

- As from the commencement of this Act, any Federal Government Ministry, Agency, Corporation or body involved in the financing, construction, operation or maintenance of infrastructure, by whatever name called, may enter into a contract with or grant concession to any duly pre-qualified project proponent in the private sector for the financing, construction, operation or maintenance of any infrastructure that is financially viable or any development facility of the Federal Government in accordance with the provisions of this Act (ICRC, 2005).

The establishment of a mother Agency to oversee all concessions was also empowered by the Act, however, this agency only started skeletal operations in 2008, and hence there is a dearth of work on PPPs in Nigeria due to the limited use of the procurement strategy in the country. The few available literature include a World Bank 2009 report cited by Akinyemi et al. (2009) who observed that "over the last decade, there has been limited success in infrastructure development in Nigeria primarily due to three major reasons which include:

- Inability by commercial banks operating in the country to generate attractive profit margins. This is mainly due to high operational costs and a lack of technical expertise in managing PPP risk.

- Significant regulatory gaps.

- Undisciplined and poor tracking of PPP project progress and delivery. This is linked to the fact that neither government nor commercial banks have generated acceptable benchmarks against which to manage risk."

Ibrahim et al. (2006) In their work identified 61 risk factors for PPP/PFI in Nigeria, out of which the ten most important:

- Unstable government

- Inadequate PPP experience

- Availability of finance

- Poor financial markets

- Land acquisition/site availability

- Availability of materials/Labour

- Financial attraction of projects to Investors

- Poor quality of workmanship

- Residual value (after concession period)

- Corruption and lack of respect for law respectively (Babalola and Odunowo, 2010)

Assessed the critical success factors of PPPs in infrastructure development in developing economy with specific reference to Nigeria and found that:

- legislation

- Cost-benefit analysis

- Creating the right environment were very important for the success of PPP projects in Nigeria

While in the Annual Infrastructure Concession Report recently submitted to the Nigerian Government, the committee responsible for the report observed that "flaws discovered in some of the concession agreements entered on behalf of the government included:

- Poor project preparation

- Inadequate definition of output requirements

- Lack of knowledge

- Non-compliance with approved Public Private Partnership procurement process"

The report further stressed that the issues identified above "had significantly undermined the success of the 
Public-Private Partnership (PPP) programme” (Shehu, 2011). And finally, (Akinyemi et al., 2009) on their part studied Nigerian Banks and their Perception of Risk in PPP Project Delivery, they found that generally, Nigerian Banks were risk averse and would prefer to transfer risks to other parties. Nigeria is in dire need of quality public infrastructure and services, in spite of all the knowledge of PPP/PFI ability to solve the country's infrastructure problems, the path towards PPPs is not still being pursued with the vigour it deserves. It is due to this that we seek to understand the constraints and barriers militating against PPPs in Nigeria.

The intentions of this paper is to isolate and rank barriers to the use of PPPs in Nigeria and suggest measures which could be taken to overcome these barriers in Nigeria in order that the much needed economic growth can be given a sound foundation to thrive. The rest of the paper is structured as follows, Literatures on PPPs in Nigeria in Section 2, reasons for adopting PPP in section 3, while section 4 deals with barriers to PPP/PFI, section 5 data presentation and analysis, while section 6 concludes.

\section{THE REASONS FOR PPP/PFI PROCUREMENT STRATEGY}

Public private partnerships evolved as a way for governments' across the globe to provide much needed public infrastructure faster than would have been provided solely using public finances. Faced with huge budget deficits, poor performance of constructed assets and the need to meet the demand of electorates for public services, which is a function of the government, the UK conservative government introduced PFI in 1992 "to reduce the public borrowing requirement by the use of private funding and also reduce the risks of time and budget overruns" (Fewings, 2005). The provision of world class public infrastructure is a prerequisite for the development and economic growth of any nation. "One of the key objectives of restructuring any state industry should be to raise productive efficiency, reduce costs and thus improve financial performance” (Andrews-Speed and Dow, 2000). Some countries have tried privatization, however, the loss of control by the government over these privatized entities resulted in higher tariffs and loss of employment due to the efficiency introduced by the private sector and has subsequently resulted in a lot of uproar on the part of the citizens. Painting a picture of how privatisation came to be viewed, (Gunawansa, 2010) observed that "total privatization of public infrastructure facilities that have provided services to the public at prices heavily subsidized by the governments was considered politically controversial. Further, the governments were hesitant to subject certain facilities to total privatization due to reasons such as interest of national security. Thus, PPP became the popular option". It is against this backdrop that Public-private partnerships came into being to restore the loss of control which had made the government unable to cushion the harsh effects of privatized entities on their citizens. The time and cost performance of the traditional procurement process was also another factors that encouraged the use of this public procurement strategy. Though, even under the traditional procurement route, the contractors have the incentive to manage time and cost overruns through the use of Liquidated and Ascertained Damages (LADs), the bundling of construction and maintenance under the PPP route provided a better option to the government. The adoption of PPP as the preferred procurement method in this era has to do with a number of factors which include, Value For Money (VFM), time and cost overruns, Quality of final products, efficiency of services delivery, reforms in governments to improve effectiveness and efficiency, creating a private sectorled economic policy, hasten development, "reduce project life-cycle costs, promote local economic growth and strengthening national infrastructure" (Pribadi and Pangeran, 2010).

\section{BARRIERS TO PPPS}

In spite of the large scale investments in PPP worldwide, a critical look at the investment patterns would suggest that those countries with high private participation share some common traits which have encouraged the private sector to get involved in public services provisions. There are a number of reasons PPPs are unable to thrive in developing countries and Nigeria in particular, outside the general inability to raise finance and the technological difference between developed and developing countries. These barriers include the following:

Political instability: The use of PPPs require the cooperation of the host government and political stability for success, this is because most of the consortium involved are usually foreign companies whose finance will be at risk should there be instability in the country where the venture is located. (Tam, 1999) "A new government always wants to impress its constituents by seeing contracts signed by the previous government as targets for attack. This kind of political atmosphere has incurred extra risks to the BOT investors whose agreements usually span 30 years", this observation reflects the Nigerian experience completely where political parties are always attacking each other's policies. (Ibrahim et al., 2006) found that unstable government was a significant risk factors for PPP in Nigeria, while writing about Thailand and the experiences of political instability in that country, (Ogunlana, 1997) also observed that "the average length of the last seven Thai governments lasted for about one year. In addition, each Thai government was 


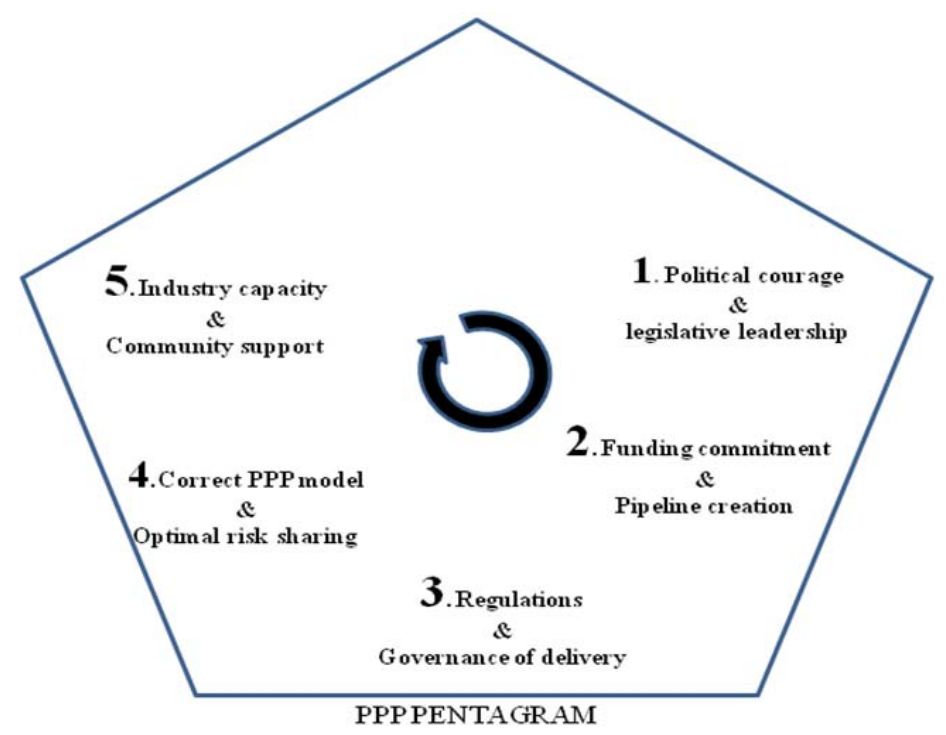

Source: Tusk Advisory, 2011

Fig. 1: Flow Chart of Hybrid Neural Network Model

a fragile coalition of sometimes more than five political parties, each with its own agenda”. Concluding, (Tam, 1999) observed that as the "political situation in developing countries is rather unstable; it is more common to have more frequent changes of government. If the new government is unwilling or unable to meet the contractual obligations, the franchisees (private supplier) will fall into difficulties" due to 'asset specificity’.

Absence of strong financial institutions: PPP consortiums rely heavily on debt finance from financial institutions, though they have to invest certain specified percentage of equity( $10-15 \%)$, the debt aspect usually makes up the larger portion of the operational capital. Takashima et al. (2010), the consortium on the other hand "also needs to have its own equity to shore up its lending ability with the banks and other financial institutions; they may also access pension funds or hedge funds in the host country. This brings the need to have strong banks and financial institutions in the host country where the project is domiciled to provide the debt finance aspect of the required capital. In China for instance, (Lou et al., 2001) affirmed that "it is foreign firms or international financial institutions rather than domestic institutions that have been involved in PPP projects".

Government policy on infrastructure: It is often government policy that drives the use of PPPs in the first place, if the government policy does not support the involvement of the private sector in public services provision, the private sector cannot bring risk capital into such countries. The Fig. 1 developed by Tusk Advisory aptly places the government as the most important consideration while developing a pentagram to explain the pre-requisite for the success of PPPs. Of the five pre-conditions identified by Tusk-Advisory (2011), Political courage and legislative leadership was perceived as the most important factor for PPP success. This was also consistent with the findings of Babalola and Odunowo (2010) who found that legislations and the creation of the right environment were among the critical success factors for PPPs in Nigeria. Improving and encouraging private sector participation in development requires the right policies to be put in place to give them the confidence to invest risk money, however, the problem is achieving the proper balance between private markets and public policy (Todaro and Smith, 2009), such that the general public is protected and the government is not criticised as being insensitive. Takashima et al. (2010) Government support in PPP contracts can take on many forms, from providing a capital subsidy in the form of one-time grant, to jointly sharing some portion of the capital investment or tax breaks.

Absence of an efficient construction industry: The success of PPPs also depends to a large extent on an efficient construction industry; this is because the inefficiencies in the construction industry were among some of the reasons for the evolution of this strategy in the first place. To understand the involvement of the construction industry, (Martimort and Pouyet, 2008) "it is useful to keep in mind that most public services (water management, waste disposal services, sanitation, public transportation, prison management) involve a complex array of tasks. Those activities necessitate indeed, first, to build infrastructures and, second, to operate these assets as efficiently as possible". In most 
developing countries and Nigeria in particular, there is a dearth of capable local construction contractors hence the bulk of large government projects are handled by foreign construction companies who possess the strength and competence required for such projects.. This is also the practice in other developing countries as was observed by Tam (1999) "In Hong Kong, most BOT projects were constructed by strong, overseas construction consortiums. They have the know-how and resources to complete the project on time and according to the quality standards". Ibrahim et al. (2006) in their study on risk factors for PPP in Nigeria found that land acquisition, non-availability of materials and labour, and poor quality workmanship were among the ten most significant risk factors out of a total of 61 risk factors identified in their study.

Absence of an effective and respectable judiciary: Construction contracting and disputes have been long time bed fellows, however the construction industry has always provided a mechanism for the peaceful resolutions of any conflicts that may arise in the course of the contracts. The problem is not the availability of the laws but that of obeying them and accepting the decisions arrived at, be it in a court of law or Arbitration panel. Ibrahim et al. (2006) also found that respect for laws was an important risk factor for PPP projects in Nigeria. There are countries where sovereign immunity still exists; it is not limited to developing countries but also in developed countries. Since PPP projects are usually large and complex, they "clearly bring together, under various contractual arrangement, differing and competing partners, interests, values and modes of rationality (ways of doing and thinking) (Marrewijk et al., 2008) which creates conflicts. The construction industry has always tried to introduce contractual safeguards to protect both parties in a contract, however "they do not fully capture the complexity of the multiple, fragmented subcultures at work in a project culture” (Kendra and Taplin, 2004) especially one that will span almost 30 years. Therefore, "to forestall these, an equitable legal system can assure investors that any disputes can be resolved quickly through litigation and make sure that both parties will respect the contract (Tam, 1999).

Corruption in government: The cost of corruption is particularly high in developing and transition countries where bribery is endemic (Transparency International, 2005) cited in Gorodnichenko and Peter, (2007). In early years , "a perception of the state as a benevolent supporter of development held sway, at least implicitly, but the record of corruption, poor governance and state capture by vested interests in so many developing countries over the past few decades has made this view untenable" (Todaro and Smith, 2009). The issues of corruption is one area where most developing countries have often failed, foreign contractors wishing to tender for projects are made to part with huge sums of monies in order to be awarded contracts. The Halliburton (BBC, 2010) and Siemens (BBC, 2007) bribery scandals in Nigeria also goes to show how far foreign multinational companies are willing to go to secure contracts in developing countries thereby helping to fuel corruption among public sector officials. Therefore, "an uncorrupted government is a key factor in the success of BOT projects (Tam, 1999) and invariably PPPs. Corruption was also among the 10 most significant risk factors for PPPs in Nigeria in the study conducted by Ibrahim et al. (2006)

Absence of a clear contract: PPP "imposes a new and more complex procurement process on the public sector, it is part tendering and part contract negotiation among public bodies, private sector consortia and their advisers" (Li et al., 2005), hence not being able to predict the future also means that certain requirements may not be covered and the contract is expected to last for over 25 years or more within which changes in technology, inflation, living conditions, government policy etc would have changed tremendously. The annual report on concessions submitted to the Nigerian government for the year 2011 found that, Poor project preparation and inadequate definition of output requirement were among the factors militating against the success of existing PPPs in Nigeria (Shehu, 2011). Therefore, the "long term nature of PFI contracts requires a clear procurement policy with provision for changes, resolving disputes, risk management, contract pricing, performance incentives and exit strategies" (Parker and Hartley, 2003). This is partly so that the private provider would not arbitrarily change its prices or the government brings undue pressure to bear on the operations of the private provider due to political exigencies.

Inadequate expertise in PPP procurement strategy: The use of PPP procurement strategy is no longer new, however, "despite the increasing use of PFI and other PPP schemes in the UK, there are still aspects of PPP which are not clear to all of the participants" (Li et al., 2005); the requirements, planning, operation and execution of PPP projects have brought with it challenges not experienced in the traditional public procurement method most public servants have become accustomed to Cartlidge (2004) observed that, "winning a PPP/PFI work is not simply about demonstrating familiarity with the 14-stage procurement process-it goes deeper than that. It involves detailed sector knowledge (health, education etc) as well as knowledge of financing, risk, EU legislation and developing innovative ways to provide and deliver public services". To further illustrate this shortage in complete knowledge of the workings of the PFI procurement 
strategy, (Public Services Privatisation Research Unit, 2000) affirmed that "The nature of PPP/PFI, with its emphasis on complex, large scale long term projects and substantial elements of risk transfer, means that a mature and sufficient private sector market has not yet been established, at least in the UK. Despite the capacity to form project consortia, there are comparatively few private sector organisations, with sufficient confidence in their own ability to make them successful, capable of taking on such projects. In turn, this restricted participation has resulted in fewer schemes reaching the contract stage" the world bank 2009 cited in Akinyemi et al. (2009), Ibrahim et al. (2006) and Shehu (2011) all affirm that lack of PPP experience and technical expertise were among the major factors militating against PPP in Nigeria.

High participation costs: The process of tendering for PPP projects involves very detailed and tedious study on the part of the consortium intending to bid for a project. The studies are necessary in order to build a solid business case to convince investors to part with risk-capital for the venture. The intending consortium will need to form a Special Purpose Vehicle (SPV), negotiate the terms of the joint venture with all firms within the SPV, make arrangements for financing and agree a suitable interest rate with the prime lenders before submitting their proposal, all these exercise require spending monies without a guarantee that the consortium will win the concession contract hence the reluctance of many contractors to participate in bidding for PPP projects. This shortcoming of the process has been recognised by the UK hence, (Fewings, 2005) "compensation is now being recommended where work is required in the detailed design stages of several bidders". One point that needs to be pointed out is that of deciding how much to reimburse the participants because all firms do not undertake the preparation of proposals in the same manner, therefore, cost of participation cannot be the same for all the firms. The problem this creates is that some firms could be under reimbursed while others could be over reimbursed if a flat rate is decided.

Fear of unemployment in the public sector: In order for PPPs to perform very well and achieve the government's objectives, there is a need for reforms in the public sector and the evolution of appropriate policy guidelines. The reforms that may occur could lead to a reduction in the staff of the public works department who may not be very happy since the PPP option will render them jobless if they are not assimilated by the concessionaire, hence they will seek every avenue available to scuttle any move that would bring their employment to a halt even though the PPP option may be in the best interest of the state. For instance, "at the back of some civil servants' minds is the realisation that the PFI indirectly reduces their raison d'etre. Decision making on policy and management matters by civil servants is reduced every time a PFI contract is signed, as responsibility is handed over to the private sector consortium” (Executive Agencies Quarterly, 1997) cited in Clark and Root (1999). Commenting further, (Todaro and Smith, 2009) observed that "Government failures may also occur in the many cases in which politicians, bureaucrat, and the individuals or groups who influence them give priority to their own private interests rather than the public interest”. In the US for instance, "the federal government spends over $\$ 66,000$ per second every second of the year. Some administrative departments and agencies have over 100,000 employees. The Department of Defense has at times employed more than a million civilians" (Rosenbloom and Kravchuk, 2005); however, when private providers take over these services with their efficiency and cost control-centered outlook to business the tendency for a lot of people to lose their jobs becomes very high.

Presence of competing projects: Generally, public services are natural monopolies which tend to generate sufficient demands like water. PPP projects are structured in a manner that provides complete guarantees to the private consortium of the ability to recoup their money within an agreed time frame. To ensure this, development of any other project that could affect the demand forecast for the private consortium's services are usually prohibited so that the forecasted demand volumes can be met by the private consortium. In Nigeria, both state and local governments can build their independent roads, hence creating an option to road users to avoid any tolled roads. In Australia for instance, a similar situation played out seriously affecting the demand on the privately financed road. In response, (Li et al., 2005) adjoining local authorities were barred (by the state) from undertaking road improvements that could directly impact adversely on the toll road traffic volumes", this directive in itself would make a government unpopular in a country like Nigeria and lead to tremendous political costs. Every state or local government politician who comes into power often seeks to award a major road project or other large civil engineering work because it is the only avenue through which large sums of money could be siphoned from the public treasury with little accountability, hence the prevalence of a lot of competing projects which may affect demand for a tolled road.

Lack of public support: When a service is provided by the public sector, more often than not, service charges are paid in most developing countries of Africa and especially Nigeria, this is true presently of services like water supply and electricity and even roads in the not 
Res. J. Appl. Sci. Eng. Technol., 5(9): 2809-2820, 2013

too distant past before the tolls were abolished, but these payments were to an extent affordable and the people could protest and be listened to by the government who saw it as its duty to provide these social services at affordable costs while thinking of reelection in the years ahead. With dwindling revenue sources available to governments in developing countries, and as Toll roads can be unpopular and carry a degree of political risk (Kettle, 2008), the governments aware of their need for public support usually avoid projects that are likely to bring about political cost because opposition political parties are waiting on the fringes to blow it out of proportion. Greater use of democratic mechanisms to control PFIs is necessary if they are to attain general acceptance (Clark and Root, 1999). A genuine concern to many is that private sector supplier with their profit emphasis and necessity to give priority to shareholders, may or may not share the same public services values that might be the case if the provision was exclusively made by those in the employment of the public sector (Broadbent and Laughlin, 2003). Apart from the general public, the civil service is another group of stakeholders whose support needs to be sought to make PPPs successful, "If many such public sector officials continue to believe that PFIs are about efficiency gains and lowering the Public Sector Borrowing Requirements (PSBR), they might block schemes. On the other hand, if they see PFIs as a measure which can provide value for money as well as enhance local and environmental quality of life, they will be likely to be more co-operative (Clark and Root, 1999). This is especially true in most developing countries in Africa where politicians clamour for belt-tightening measures while they refuse to cut down on their own personal spending. Under such situations, public sector officials would tend not to support the move to PPPs being aware of the volume of resources available and how politicians are spending wastefully on personal welfare.

Lack of consensus on infrastructure priorities amongst policy makers: There are few countries in Africa that have a homogeneous population; most African countries are a loose collection of various ethnic groups. Busse and Hefeker (2007) “This applies in particular to sub-Saharan Africa, where ethnic fragmentation is much greater in comparison to other regions". In the case of Nigeria, with a multi-ethnic population spread across the country there is pressure on their various representatives in government to win over or influence development projects to their constituencies thereby creating enormous competition for the limited number of projects within the central government's annual infrastructure plan. "It is argued that an enlightened central government, through its economic plan, can best provide the needed incentives to overcome the inhibiting and often divisive forces of sectionalism and traditionalism in a common quest for widespread material and social progress" (Todaro and Smith, 2009), however, often times, the bias usually starts at the central government level or from the dominant ethnic group in government leading to an environment where consensus is difficult to reach on priority projects that would support economic growth. And since PPPs have to be planned centrally and connected with the general macroeconomic policy of government, it then means that even where financing is available, certain areas would take priority over others. This leads to conflicts within the government and among politicians.

Lack of adequate security: Business thrives in an atmosphere of security; hence where this is absent there is bound to be investor apathy. "Africa has never been a major recipient of Foreign Direct Investments (FDI) flows and so lags behind other regions of the world. On an annual average basis, the region's share of global FDI inflows was $1.8 \%$ in the period 1986-1990 and $0.8 \%$ in the period 1999-2000" (Dupasquier and Osakwe, 2006). This cannot be unconnected with the relative unease that exist in most parts of the continent coupled with the near absence of most basic infrastructure. Busse and Hefeker (2007) In their study of the relationship between Political risk, institutions and foreign direct investment, found that "in particular government stability, internal and external conflicts, law and order, ethnic tensions, bureaucratic quality and, to a lesser degree, corruption and democratic accountability are important determinants of foreign investment flows". Corroborating their findings, (Dupasquier and Osakwe, 2006) also observed that, "experience has shown that if a host country creates an environment conducive to investment, FDI can play an important role in its development efforts". In the Nigerian context, the kidnapping of multi-National expatriate workers has become a big money spinner for jobless youths in the restive Niger-Delta area of the country, hence the lethargy to accept and deliver infrastructure contracts by capable foreign firms in those regions.

\section{METHODOLOGY}

A literature review was conducted to identify prevailing barriers to the use of PPP/PFI across the globe because literature on PPP/PFI in Nigeria is limited; this is not unconnected with the nascent nature of the practice of PPP/PFI in Africa and Nigeria in particular. The PPP/PFI agency in Nigeria, Infrastructure Concession and Regulatory Commission (ICRC) was created in 2008 even though the Act establishing it became law in 2005, limiting the discussion of PPP/PFI in Nigeria to a few publications. However, the Postal questionnaires were distributed in 
Res. J. Appl. Sci. Eng. Technol., 5(9): 2809-2820, 2013

Nigeria among Public sector construction professionals involved in procuring and managing public infrastructures on behalf of government including staff of Nigeria's concession regulatory agency, the ICRC. 50 postal questionnaires designed using the 5-point likert scale rating format were sent out to construction professionals working within the public works ministry, the PPP/PFI regulatory agency and the agency responsible for the Federal capital city's public infrastructures, all in Nigeria. Thirty one respondents returned their completed questionnaires which were then analysed using SPSS statistical software version 17.0. A test of internal consistency of the responses produced a Cronbach's Alpha co-efficient of 0.728 which lies between the boundaries of acceptable following the guide provided by George and Mallery (2003) viz: “_> .9-Excellent, _- .8-Good, _ > .7Acceptable, ${ }_{-}>$.6-Questionable, ${ }_{-}>$.5-Poor, and ${ }_{-}<$ .5-Unacceptable" (p. 231). While increasing the value of alpha is partially dependent upon the number of items in the scale, it should be noted that this has diminishing returns (Gliem and Gliem, 2003).

The descriptive statistics obtained were then used to calculate the Relative Importance Index (RII) of the barriers listed and the possible solution factors presented to the respondents in the questionnaires. The Relative Importance Index helps rank factors based on the number of respondents who ticked a particular factor. The RII used to rank the factors identified in this study, has been used in the past by Odusami (2002) to rank the most important skills of effective project leaders, though he used a 4-point likert scale for his study while we are adopting a 5-point likert scale for our study.

Relative Importance Index (RII)

$$
\begin{aligned}
& \text { RII }=5 n_{5}+4 n_{4}+3 n_{3}+2 n_{2}+1 n_{1} \\
& \quad 5 \times \text { N }
\end{aligned}
$$

where $n_{5}$ is the number of respondents who ticked Strongly Agree, $\mathrm{n}_{4}$ for the number of respondents for Agree, $\mathrm{n}_{3}$ for the number of respondents for Neither Agree Nor Disagree, $\mathrm{n}_{2}$ for the number of respondents for Disagree, while $n_{1}$ is for the number of respondents for Strongly Disagree, for the denominators in the Eq. (5) (highest weighing or highest number on the Likert scale) and $\mathbf{N}$ for total number of respondents.

\section{DATA ANALYSIS, DISCUSSION AND FINDINGS}

Table 1 shows a breakdown of the respondents according to professional roles within the civil service, qualifications at the time of the study, and the number of years in service at the time of the study. From the profile of the respondents, it can be seen that they all possess adequate academic, professional and length of

\begin{tabular}{|c|c|c|c|c|c|}
\hline Profession & No. & Qualifications & No. & $\begin{array}{l}\text { No of years } \\
\text { served }\end{array}$ & No. \\
\hline Architects & 3 & $\begin{array}{l}\text { Ph.D } \\
\end{array}$ & 1 & $\begin{array}{l}10 \text { years and } \\
\text { above }\end{array}$ & 13 \\
\hline Engineers & 9 & M.Sc & 10 & 7-10 years & 6 \\
\hline Q/Surveyors & 7 & B.Sc & 13 & 4-6 years & 4 \\
\hline $\begin{array}{l}\text { Project } \\
\text { managers }\end{array}$ & 5 & Diploma & 7 & $1-3$ years & 8 \\
\hline Other & 7 & & & & \\
\hline Total & 31 & & 31 & & 31 \\
\hline
\end{tabular}

Table 1: Profile of respondents

Table 2: Ranking of barriers to PPP public sector perspective Ranking of barriers to PPP by public

$\begin{array}{ll}\text { sector } & \text { RII values } \\ \text { Corruption in government } & 0.87 \\ \text { Government policy on infrastructure } & 0.77 \\ \text { Lack of security } & 0.73 \\ \text { Lack of consensus on infrastructure } & 0.72 \\ \text { priorities among policy makers } & \\ \text { High participation cost } & 0.70 \\ \text { Political instability } & 0.68 \\ \text { Absence of strong financial institutions } & 0.68 \\ \text { Absence of a clear contract } & 0.67 \\ \text { Lack of expertise } & 0.63 \\ \text { An efficient construction industry } & 0.61 \\ \text { Absence of an effective and respectable } & 0.59 \\ \text { judiciary } & \\ \text { Lack of public support } & 0.56 \\ \text { Fear of unemployment } & 0.56 \\ \text { Presence of competing projects } & 0.54 \\ \text { Solution factors to overcome barriers to } & \text { RII Values } \\ \text { PPP } & \end{array}$
PPP

service experience to adequately give a reasonable verdict on the subject of the study.

From the RII calculated, the values obtained were sorted in descending order and shown on Table 2. The results shows that corruption in government (RII = 0.87 ) was ranked as the most significant barrier to the use of PPP for the provision of public services, this finding has very serious implication for policy makers because the survey respondents are civil servants working for the government. Corrupt people have rarely been known to own up to accusations of corruption, therefore what this seems to suggest is that the political heads of these ministries and the senior executives are either involved in corrupt practices or shield those doing so. Government policy on infrastructure (RII = 0.77) was ranked as the second major barrier to the use of PPPs, this finding validates the quality of respondents, as it shows clearly that as civil servants, the respondents have a very sound understanding of the link between their works and policy related issues. "The civil service has to meet two somewhat contradictory requirements. On the one hand, it is responsible for fulfilling goals set up by the ruling political party. On the other hand, it has to provide politicians with professional, unbiased advice and expertise, both in policy making and implementation” (Bekke and Meer, 2000) cited in Gajduschek (2007). The third major barrier as identified by the respondents is Lack of Security (RII $=0.73)$, this issue has taken a more dangerous dimension owing to the huge sums of money 
Res. J. Appl. Sci. Eng. Technol., 5(9): 2809-2820, 2013

which some kidnappers in the restive Niger-Delta area of the country have made in the last couple of years. The kidnap of foreign expatriate workers has become a big money spinner with some resulting in deaths hence discouraging capable foreign contractors from accepting projects in these areas. Growth has generally been shown to be positive under peaceful secure environments rather than areas prone to conflicts.

Lack of consensus on infrastructure priorities among policy makers $(\mathrm{RII}=0.72)$ ranked fourth place and this can be explained in the context of the many ethnic groups competing for projects to be cited in their geographical area through their representatives in parliament, furthermore, "Many governments face difficult decisions as they try to balance budgets whilst continuing to invest in infrastructure. Prioritization of infrastructure development is critical to maintain economic growth and address the needs arising from a growing global population” (KPMG, 2010). High participation costs (RII $=0.70)$ ranked fifth among the major barriers to PPPs in Nigeria. Effective and respectable judiciary $(\mathrm{RII}=0.59)$, lack of public support $(\mathrm{RII}=0.56)$, fear of unemployment $(\mathrm{RII}=$ $0.56)$ and presence of competing projects $(\mathrm{RII}=0.54)$ were all considered not to be of serious significance by the respondents as calculated from their Relative Importance Index (RII). The only factor among the barriers whose ranking is a little troubling is the 'fear of unemployment" (RII $=0.56$ ) factor, this is because when the private sector takes over services provision and introduce efficiency measures, a lot of civil servants are prone to lose their jobs or are made redundant as was shown in NAO (2008), hence the concern for the troubling position the factor occupies in the ranking of barriers. However, it may be that they do not fully grasp the consequences resulting from the adoption of PPPs.

The respondents were also presented with a list of possible solutions that can help overcome the slow uptake of PPPs in Nigeria to rate on a 5-point likert scale and the result of the RII calculations obtained are presented below in Table 3 .

The Elimination of corruption (RII $=0.85)$ and Improving the knowledge of professionals in PPP strategy $(\mathrm{RII}=0.85)$ both tied with the same RII values, hence were ranked as the most important solution factors to help in overcoming the barriers to PPPs in Nigeria, this finding reaffirms the findings of Akinyemi et al. (2009), Ibrahim et al. (2006) and Shehu (2011) who found that there is inadequate PPP experience and expertise in the Nigeria PPP market comprising both government players and the private sector providers. However, the ranking is a bit puzzling considering the fact that "lack of expertise" ranked a faraway $9^{\text {th }}$ position when barriers to PPP were ranked by the respondents from Table 2 . The third most important solution factor ranked by the respondents was
Table 3: Public sector ranking of solution factors

\begin{tabular}{|c|c|c|}
\hline 1 & Elimination of corruption in government & 0.85 \\
\hline 2 & $\begin{array}{l}\text { Improving knowledge of professionals in PPP } \\
\text { strategy }\end{array}$ & 0.85 \\
\hline 3 & Improving policy on infrastructure & 0.84 \\
\hline 4 & Political stability & 0.81 \\
\hline 5 & Developing strong financial institutions & 0.81 \\
\hline 6 & Stakeholder involvement and sensitisation & 0.81 \\
\hline 7 & Improvement in security & 0.81 \\
\hline 8 & $\begin{array}{l}\text { Setting priorities on infrastructure among } \\
\text { policy makers }\end{array}$ & 0.80 \\
\hline 9 & Proper cost-benefit analysis & 0.79 \\
\hline 10 & A clear contract/toll review mechanism & 0.77 \\
\hline 11 & $\begin{array}{l}\text { Joint venture with foreign firms to enable } \\
\text { technology transfer }\end{array}$ & 0.76 \\
\hline 12 & Reduction in participation cost & 0.74 \\
\hline 13 & $\begin{array}{l}\text { Guaranteeing demand/absence of competing } \\
\text { projects }\end{array}$ & 0.71 \\
\hline 14 & $\begin{array}{l}\text { Effective respectable and independent } \\
\text { judiciary }\end{array}$ & 0.70 \\
\hline 15 & $\begin{array}{l}\text { Staff transfer agreement to reduce } \\
\text { unemployment }\end{array}$ & 0.68 \\
\hline
\end{tabular}

“improving policy on infrastructure" $(\mathrm{RII}=0.84)$, this further proves that the respondents have a very sound understanding of the role of policy in changing the way government operates and also drives home the importance of their position as civil servants in helping to achieve government's strategic goals. This finding is also consistent with the study by Babalola and Odunowo (2010) who found among other things that legislation and creating the right environment were vital factors in the success of PPPs in Nigeria. Surprisingly, four solution factors tied with Relative Importance Index (RII $=0.81)$, they include 'political stability', 'Developing strong financial institutions', 'Stakeholder involvement and sensitization' and 'improvement in security'; all the four tied solution factors fall under the direct duties of the government or areas where they can indirectly use policy instruments to regulate. Ibrahim et al. (2006) also found that unstable government was the most important risk factor for PPPs in Nigeria, while (Akinyemi et al., 2009) in their work found that Nigeria banks were seriously risk averse in regard to PPPs financing. Setting priorities on infrastructure among policy makers $(\mathrm{RII}=0.80)$ closed up the RII values ranging from $0.85-0.80$ consisting of 8 factors in all. Looking at the two tables presented one above and one below, one thing is conspicuously noticed, there seem to be a higher agreement between the respondents on the solution factors than the barrier factors as can be seen from the number of factors that hit the 0.80 and above RII values. Only one (1) factor reached the 0.80 RII value for the barriers tables, while eight (8) solution factors hit the 0.80 RII values. Staff transfer agreement to reduce unemployment $(\mathrm{RII}=0.68)$ was ranked as the least significant solution factor and surprisingly, it is the only factor that has an RII value below 0.70 on the table. It is difficult to explain the reason behind this clearly; however, one explanation would be the near absence of operational PPP projects that would have 
provided the public sector staff an insight into the adverse effect of this strategy on the public sector staff strength. In the UK (NAO, 2008) and Malaysia (EPU, 2001) after PPPs and privatizations were embarked upon, there occurred a huge transfer of public sector staff to the private provider or consortium who are usually efficiency driven hence may not assimilate all the transferred staff. In countries where the effects of private participation in infrastructure have been felt, "there is widespread perception that the reforms have hurt the poor, notably through increases in prices and unemployment while benefitting the powerful and wealthy notably through corruption" (Auriol and Blanc, 2009). While the presence of respectable judiciary would be a pre-requisite considered by foreign investors, and was an important rsik factor in the study by Ibrahim et al. (2006), it somehow did not seem to be significant from the public sector perspective as shown by the position of the factor on both the barriers and solution tables where it occupied $11^{\text {th }}$ and $14^{\text {th }}$ position respectively.

\section{CONCLUSION}

Public private partnerships are going to be around for a while longer because it has helped a lot of developed and developing countries to upgrade and provide public infrastructures faster than would have been possible if they relied solely on tax revenue. The present state of infrastructure development in Nigeria has become a national problem drawing criticism from the electorates, especially against the backdrop of being the largest producer of crude oil in Africa and the enormous revenue accruing to the government through crude oil sale. However, there are other areas requiring government attention financially which makes PPPs a handy tool to cater for the infrastructure aspects of the governments duties. In spite of the proven ability of this public procurement strategy, it has refused to fly in Nigeria due to corruption in government, government policy on infrastructure, security challenges and high participation costs. These findings are important and have serious implications for attracting investors who play a very important role in the PPP market. While it may not be easy to eliminate all the barriers identified in the study, the political will to embrace the PPP route would help cut the level of corruption. However, the government should ensure it has trained sufficient staff in PPP procurement strategy before embarking on it to prevent expensive buy-back schemes or excessive profiteering by the private provider which can result in huge political costs to the government. The findings in this study also have serious implications which should be considered by private investors wishing to invest in infrastructure provisions in Nigeria and Africa at large. One important action that should be taken by investors wishing to go ahead with investments in Nigeria will be to seek sovereign guarantees for their investments or evoking the assistance of countries with bilateral ties with Nigeria to receive payments on their behalf and pass it to the concessionaire through the use of Escrow accounts.

However, the most significant finding in this study suggest that very serious work needs to be done by the government on itself, its ministers and senior civil servants within its various ministries through purging out those who are corrupt. The fact that the respondents in this study were all civil servants involved in service delivery and they all agreed that corruption is the most significant barrier to PPPs in Nigeria speaks volumes about the role of government and its agencies. However, corruption does not take place in a vacuum and public sector officials cannot trade corruption with each other rather corruption is precipitated through the interaction of public and private official, therefore the prospective private sector investors equally have a couple of things to learn which would assist them in their strategic planning exercise when entering into infrastructure provision in the African Sub-Continent. Though the questionnaires were distributed in Nigeria, the situation in many other African countries is not much different. The government should also ensure it appoints knowledgeable and competent hands with the required technical and professional qualifications to head the public works department and its subministries. Where the required expertise are absent, reputable consultants can be used to fill the gap in the short-term while endeavoring to provide long-term solutions to such skills gap through training, seminars, workshops and conference sponsorship.

\section{REFERENCES}

Akinyemi, B., U. Ojiako, S. Maguire, G. Steel and A. Anyaegbunam, 2009. Nigerian banks and the perception of risk in PPP project delivery. J. Financ. Manage. Public Serv., 8(2).

Andrews-Speed, P. and S. Dow, 2000. Reform of China's Electric Power Industry challenges facing the Government. Energy Policy, 28: 335-347.

Ang, J.B., 2008. Determinants of foreign direct investment in Malaysia. J. Policy Model., 30: 185189.

Auriol, E. and A. Blanc, 2009. Capture and corruption in public utilities: The cases of water and electricity in sub-saharan Africa. Utilities Policy,17: 203-216.

AusCID, 2002. PFP Projects. Sydney: Australian Council for Infrastructure Development.

Babalola, J. and O. Odunowo, 2010. Assesment of critical success factors of Public-Private Partnerships (PPP) on infrastructure development in developing economy. Second International Conference on Construction in Developing Countries (ICCIDC-II), Advancing and Integrating Construction Education, Research \& Practice, Cairo, pp: 623-628. 
Res. J. Appl. Sci. Eng. Technol., 5(9): 2809-2820, 2013

BBC, 2007. Nigeria Probes Siemens Bribe Case. Retrieved from: BBC News: http://news.bbc.co.uk/2/hi/africa/7105582.stm, (Accessed on: August 14, 2011).

BBC, 2010. Dick Cheney Faces Bribery Scandal Charges in Nigeria. Retrieved from: BBC News Africa: http://www.bbc.co.uk/news/world-africa11902489, (Accessed on: August 14, 2011).

Bekke, H. and F. Meer, 2000. Civil Service Systems in Western Europe. Cheltenham, Edward Elgar, UK, pp: 281-282.

Benito, B., V. Montesinos and F. Bastida, 2008. An example of creative accounting in public sector: The private financing of infrastructures in Spain. Crit. Perspect. Account., 19: 963-986.

Blanc-Brude, F., H. Goldsmith and T. Välilä, 2009. A comparison of construction contract prices for traditionally procured roads and public-private partnerships. Rev. Indus. Organ., 35: 19-40.

Broadbent, J. and R. Laughlin, 2003. Public-private partnerships: An 9. Account. Audit. Accountability J., 16(3): 332-341.

Busse, M. and C. Hefeker, 2007. Political risk, institutions and foreign direct investment . Eur. J. Polit. Econ., 23: 397-415.

Cartlidge, D., 2004. Procurement of Built Assets. Elsevier Butterworth-Heinemann, Oxford.

Clark, G.L. and A. Root, 1999. Infrastructure shortfall in the United Kingdom: The private finance initiative and government policy. Political Geogr., 18: 341-365.

De Brux, J., 2010. The dark and bright sides of renegotiation: An application to transport concession contracts. Utilities Policy, 18: 77-85.

Dupasquier, C. and P.N. Osakwe, 2006. Foreign direct investment in africa: performance, challenges and responsibilities. J. Asian Econ., 17: 241-260.

English, L.M. and J. Guthrie, 2003. Driving privately financed projects in Australia: What makes them tick? Account. Audit. Accountability J., 16 (3): 493-511.

EPU, 2001. Eight Malaysian Plan. Economic Planning Unit, Retrieved from: http://www.epu.gov.my/html/themes/epu/images/c ommon/pdf/8th-msia-plan-c7-cont.pdf, (Accessed on: August 18, 2011).

EPU, 2010. Tenth Malaysian Plan. Economic Planning Unit, Retrieved from: http://www.epu.gov.my/html/themes/epu/html/RM KE10/rmke10-english.html, (Accessed on: August 17, 2011).

Fewings, P., 2005. Construction Project Management: An Integrated Approach. Taylor \& Francis, Abingdon.

Gajduschek, G., $2007 . \quad$ Politicisation, professionalisation, or both? hungary's civil service system. Communis. Post-Commun., 40: 343-362.
George, D. and P. Mallery, 2003. SPSS for Windows Step by Step: A Simple Guide and Reference 11.0 Update. 4th Edn., Allyn \& Bacon, Boston.

Gliem, J.A. and R.R. Gliem, 2003. Calculating, Interpreting, and Reporting Cronbach's Alpha Reliability Coefficient for Likert-Type Scales. Midwest Research-to-Practice Conference in Adult, Continuing and Community Education, The Ohio State University, Ohio.

Gorodnichenko, Y. and K.S. Peter, 2007. Public sector pay and corruption: Measuring bribery from Micro Data. J. Public Econ., 91: 963-991.

Gunawansa, A., 2010. Is there a need for Public Private Partnerships Projects in Singapore? The Construction, Building and Real Estate Research Conference of the Royal Institution of Chartered Surveyors. Paris, RICS, France.

HM Treasury, 2006. Strengthening Long Term Partnerships. HM Treasury, London.

Ibrahim, A., A. Price and A. Dainty, 2006. The analysis and allocation of risks in public private partnerships in infrastructure projects in Nigeria. $\mathrm{J}$ Financ. Manage. Property Constr.,11(3): 149-163.

ICRC, 2005. Infrastructure Concession Regulatory Commission (Establishment, etc) Act, 2005. Infrastructure Concession Regulatory Commission, Abuja.

Kendra, K. and T. Taplin, 2004. Project success: A cultural framework. Proj. Manage. J., 35(1): 30-45.

Kettle, H., 2008. New Zealand PPPs-Work in Progress. Retrieved from: Bellgully: http://www.bellgully.com/resources/resource.0164 3.asp, (Accessed on: January 18, 2011).

KPMG., 2010. The Changing Face of Infrastructure: Public Sector Perspectives. KPMG International, UK.

Li, B., A. Akintoye, P. Edwards and C. Hardcastle, 2005. Perceptions of Positive and Negative factors influencing the attractiveness of PPP/PFI procurement for construction projects in the UK: Findings from a questionnaire survey. Eng. Constr. Arch. Manage., 12(2): 125-148.

Lou, J., A. Gale and X. He, 2001. Investing in the Chinese construction industry via joint ventures. Build. Res. Inf., 32(2): 277-285.

Marrewijk, A., S. Clegg, T. Pitsis and M. Veenswijk, 2008. Managing public-private partnerships: paradoxes, complexities and project design. Int. J. Proj. Manage., 26: 591-600.

Martimort, D. and J. Pouyet, 2008. To build or not to build: normative and positive theories of publicprivate partnerships. Int. J. Ind. Organ., 26: 393411.

NAO, 2008. Protecting Staff in PPP/PFI Deals. National Audit Office, London.

Odusami, K.T., 2002. Perceptions of construction professionals concerning important skills of effective project leaders. J. Manage. Eng., 18: 6167. 
Res. J. Appl. Sci. Eng. Technol., 5(9): 2809-2820, 2013

Ogunlana, S., 1997. Build-Operate-Transfer Procurement Traps: Examples from Transportation Project in Thailand. Proceedings of the CIB W92 Symposium on Procurement, Montreal.

Parker, D. and K. Hartley, 2003. Transaction costs, relational contracting and public private partnerships: A case study of UK defence. J. Purchasing Supply Manage., 9: 97-108.

Pribadi, K. and M.H. Pangeran, 2010. Assessing readiness of public sector risk management for PPP in infrastructure development in Indonesia. Second International Conference on Construction in Developing Countries(ICCIDC-II): "Advancing and Integrating Construction Education, Research \& Practice, Cairo, pp: 217-280.

Public Services Privatisation Research Unit, 2000. Private Finance Initiative: Dangers, Realities and Alternatives. UNISON, London.

Roger, N., 1999. Recent Trends in Private Participation in Infrastructure. World Bank.
Rosenbloom, D.H. and R.S. Kravchuk, 2005. Public Administration:Understanding Management Politics and Law in the Public Sector. 6th Edn., McGraw-Hill Inc., New York.

Shehu, M.S., 2011. ICRC Uncovers Fraud in FG's Concession Agreements. Retrieved from: DailyTrust:

http://dailytrust.com.ng/index.php?option=com content\&view=article\&id=28707:icrc-uncoversfraud-in-fgs-concession-agreements\&catid=2:leadstories\&Itemid=8, (Accessed on: October 2, 2011).

Siang, L.Y., 2008. Private finance initiativesinfrastructure and utilities development. Ingenieur J., 36: 6-9.

Takashima, R., K. Yagi and H. Takamori, 2010. Government guarantees and risk sharing in publicprivate partnerships. Rev. Financ. Econ., 19: 78-83. 